\title{
The Effects of Assisted Circulation by Intraaortic Balloon Pumping and Shunting of the Left Ventricle on Myocardial Damage after Coronary Artery Ligation in Dogs
}

\author{
M. S. Margulis, M.D., B. K. Mordashev, M.D., \\ K. A. Kuznecov, M.D., L. I. Ponomareva, M.D., \\ and J. A. Sorokin, M.D.
}

\section{SUMmaRY}

The purpose of this study is to determine the effects of different kinds of assisted circulation (AC) on the intensity of ischemic and necrotic processes in experimental myocardial infarction in dogs. Three types of experiments were carried out. In the first group, the infarction was modelled by surgical ligation of a branch of the descending artery. In the second group, AC by intraaortic balloon counterpulsation was started 15 min after coronary occlusion and lasted for 2 hours. In the third group, $\mathrm{AC}$ was carried out by means of left ventricular drainage with transaortic insertion of a catheter, and a subsequent forcing of the blood into the femoral artery. During the experiment, 10 epicardial leads were recorded and the number of points registering a considerable displacement of segment $\mathrm{ST}(\mathrm{nST})$ as well as the total displacement of segment ST ( $\sum S T$ ) were analysed. The size of the necrotic zone in the myocardial wall was identified macroscopically.

The results testify to the favourable effects of both methods of $\mathrm{AC}$ on the intensity of destructive myocardial processes. The effect on ST was recorded soon after the beginning of AC. The effect on $\sum \mathrm{ST}$ was less pronounced and was observed at a later stage (after 30-45 $\mathrm{min}$ ). In the histochemical investigation of the necrotic zone of the myocardial wall, the positive effects were more marked in the extracorporeal bypass of the left ventricle, which showed the size of myocardial infarction to be much smaller $(p<0.05)$ than in the group with intraaortic balloon pumping. These experimental data are indicative of a significant positive effects of $\mathrm{AC}$. In particular, shunting of the left ventricle caused a marked decrease in myocardial necrosis.

From the Department of Experimental Surgery, Medical Institute of Riga, 226047, 12 boulv. Padomju, Riga, Latvia, U.S.S.R.

Received for publication February 13, 1981.

Manuscript revised June 2, 1981. 
SSISTED circulation (AC) is an alternative method of treating acute cardiac insufficiency. ${ }^{1)}$ The present means of assisting the weakened myocardium can be grouped according to two principles: 1) diminished afterload (decreased aorta impedance) and 2) decreased preload. ${ }^{2,3}$ Intraaortic balloon counterpulsation is the best example of the first type of AC method. Its simplicity, safety, and high effectiveness have made it a standard for the usefulness of other assisted circulation methods. The second type of AC method consists of shunting part of the blood from the left atrium or left ventricle to the aorta or a peripheral artery, thus diminishing the work of the left ventricle. Research in this field was initiated by Dennis et al," who published a method for unloading the left ventricle via a rigid cannula, passed through the septum into the left atrium. A number of reports have been published on the use of blood drainage from the left atrium ${ }^{5)}$ or left ventricle, ${ }^{6,7)}$ and transarterial unloading of the left ventricle has been used clinically with considerable success. ${ }^{8)}$

The aim of our experiments was to compare the efficiency of two methods of AC: intraaortic balloon counterpulsation and transarterial blood drainage from the left ventricle. The efficiency of these methods was compared by electrocardiographic recordings of the displacement of segment ST from the epicardial leads, as well as by macroscopic identification of the necrotic lesions of the myocardium.

\section{Materials and Methods}

Twenty-six mongrel dogs (mainly male) weighing from 24 to $35 \mathrm{Kg}$ (average $27.8 \mathrm{Kg}$ ) were used in our experiments. They were divided into 3 groups: a control group and 2 groups for investigation of 1) the influence of $\mathrm{AC}$ by intraaortic counterpulsation and 2) blood drainage from the left ventricle. The control group consisted of 10 dogs. After premedication with neuroleptanalgesic drugs (fentanil $0.01 \mathrm{mg} / \mathrm{Kg}$, droperidol $0.25 \mathrm{mg} / \mathrm{Kg}$ ) and atropine $(6-8 \mathrm{mg})$, they were anaesthetized by repeated fractional administration of hexenal. Respiration was maintained by endotracheal intubation with an air-oxygen mixture. A left thoracotomy was performed in the fourth or fifth intercostal space and the pericardium was opened. The apical branch leading from the descending coronary artery was ligated. The following parameters were recorded simultaneously: electrocardiogram, left ventricular pressure (via a catheter passed through the left auricle), arterial pressure in the aortic arch (via a catheter passed through the brachial artery), and cardiac output with an electromagnetic flowmeter. The heparinization of dogs was performed at a rate of $2 \mathrm{mg} / \mathrm{Kg}$ of body weight. Blood samples were 
drawn periodically to investigate a number of biochemical indices.

Epicardial ECG leads from the frontal surface of the left ventricle were recorded by the methods of Maroko et a ${ }^{99}$ with special electrodes located at 10 sites. Six recording sites were in the immediate proximity of the ischemic area. Epicardial leads were registered immediately after the ligation of a branch of the descending coronary artery, and additional records were taken every $15 \mathrm{~min}$ for 2 hours and $15 \mathrm{~min}$. After completion of recording from the epicardial leads, the chest was sutured layer by layer leaving a drainage in the pleural cavity. A pathomorphological investigation of the heart was carried out after the dog's death, but not later than 24 hours after the ligation of the coronary artery.

The size of necrosis arising after the ligation of the coronary artery was determined by the procedure of Nachlas and Schnitka. ${ }^{10)}$ The myocardial sections $(1 \mathrm{~cm}$ thick) were stained, the necrotic area was excised, weighed and its volume was determined by means of removing liquid from a measuring cavity. Similar studies were performed on the whole left ventricle. The projection area of the zone of myocardial infarction upon the frontal surface of the left ventricle was measured in accordance with the spread of the necrosis in the myocardial wall.

The preparatory stages in the second group of experiments (8 dogs) was analogous to those for the control group. In addition, one of the femoral arteries or the common iliac artery of the animal was exposed for inserting the intraaortic balloon. The end of the balloon was situated just below the bifurcation of the left subclavian artery. The balloon-pump was synchronized with the " $R$ " wave of ECG. Intraaortic balloon counterpulsation started $15 \mathrm{~min}$ after the ligation of a branch the descending coronary artery and lasted for 2 hours. Intraaortic balloon pumping was realised by a dual-chambered balloon with $23 \mathrm{~cm}^{3}$ volume. The systolic pressure of balloon inflation was about $150 \mathrm{mmHg}$, the diastolic balloon pressure was created by $40 \mathrm{mmHg}$ of vacuum.

The third group also consisted of 8 dogs on whom a bypass shunting of the left ventricle was performed. Blood was drawn through a catheter with a $4 \mathrm{~mm}$ inner diameter, inserted through the left subclavian artery into the left cardiac ventricle. The blood from the left ventricle was collected into a cylinder and was forced into the femoral artery by means of a roller pump. The mean output of the pump was $1,100 \mathrm{ml} / \mathrm{min}$ (from 31 to $45 \mathrm{ml} / \mathrm{min} / \mathrm{Kg}$ ), equivalent to about $44 \%$ of cardiac output. A reservoir included in the circuit of the outer shunt served to control the volume of the extracorporeal shunt and as an air trap.

The following indices have been analysed in the present study: total rise 
of segment ST in epicardial leads $(\Sigma S T)$, number of recording points of epicardial leads where the displacement of segment ST was equal or exceeded $2 \mathrm{~mm}$ ( $\mathrm{nST}$ ), and the size of myocardial necrosis in the left ventricular wall.

\section{Results}

The following data were obtained from the first group. Immediately after ligation of the coronary artery, the total displacement of segment ST was equal to $4.4 \pm 0.5 \mathrm{~cm}$ (Table I). The maximum value of this index was recorded 75 and $90 \mathrm{~min}$ after coronary occlusion. Subsequently, ST decreased and was equal to its initial value $(3.8 \pm 0.4 \mathrm{~cm})$ in 2 hours and $15 \mathrm{~min}$. The number of points with considerable segment ST displacement behaved similarly. The maximum $\mathrm{nST}$ rise was recorded between 1 hour and 1 hour 45 min after ligation and fluctuated around 9.0, and decreased towards the end of the observation period (Table II).

The following data were obtained from the second group with intraaortic counterpulsation. The maximum $\sum \mathrm{ST}$ rise was recorded $15 \mathrm{~min}$ after the ligation of the coronary artery $(6.7 \pm 0.6 \mathrm{~cm})$. At a later stage, when intraaortic counterpulsation was started, a progressive decrease of this index was noted. Starting with the 45 th min after the ligation of the coronary artery or at the 30th min of $A C, \sum S T$ fluctuated between $3.6 \pm 0.3 \mathrm{~cm}$ and $4.1 \pm 0.9 \mathrm{~cm}$. In this group, $\mathrm{nST}$ increased sharply within $15 \mathrm{~min}$ after the ligation of the coronary artery, and from with the 30th min and up to the end of $\mathrm{AC}$, this index stabilized at an average of about 6.0.

In the group with a bypass of the left ventricle, the maximum value of $\sum \mathrm{ST}$ was recorded immediately after ligation $(5.1 \pm 0.9 \mathrm{~cm})$ and prior to the onset of $\mathrm{AC}(5.8 \pm 1.4 \mathrm{~cm})$. While the shunt was functioning, this index decreased gradually and stabilized at about $4.0 \mathrm{~cm}$, especially in the second half

Table I. Changes of $\sum S T$ in the Control and Assisted Circulation Groups in Dogs

(Mean士S.E.)

\begin{tabular}{|c|c|c|c|c|c|c|c|c|c|c|c|}
\hline $\begin{array}{l}\text { Time } \\
\Sigma \mathrm{ST}\end{array}$ & & $\begin{array}{l}\text { Ligation } \\
\text { of } \\
\text { coronary } \\
\text { artery }\end{array}$ & $\begin{array}{r}15 \\
\min \end{array}$ & $\begin{array}{r}30 \\
\min \end{array}$ & $\begin{array}{r}45 \\
\min \end{array}$ & $\begin{array}{r}60 \\
\min \end{array}$ & $\begin{array}{r}1 \mathrm{~h} \\
15 \\
\min \end{array}$ & $\begin{array}{r}1 \mathrm{~h} \\
30 \\
\mathrm{~min}\end{array}$ & $\begin{array}{r}1 \mathrm{~h} \\
45 \\
\mathrm{~min}\end{array}$ & $2 \mathrm{~h}$ & $\begin{array}{r}2 \mathrm{~h} \\
15 \\
\text { min }\end{array}$ \\
\hline \multirow[t]{2}{*}{ Control (cm) } & $\mathbf{M}$ & 4.4 & 6.0 & 5.6 & 6.0 & 5.9 & 7.4 & 7.5 & 7.0 & 4.9 & 3.8 \\
\hline & S.E. & 0.5 & 1.2 & 0.9 & 1.4 & 0.9 & 0.8 & 0.5 & 0.8 & 1.2 & 0.4 \\
\hline \multirow[t]{2}{*}{$\operatorname{IABP}(\mathrm{cm})$} & $\mathbf{M}$ & 4.0 & 6.7 & 6.3 & 4.8 & 4.0 & 3.9 & 3.6 & 4.0 & 4.1 & 3.7 \\
\hline & S.E. & 0.6 & 0.6 & 0.1 & 0.6 & 0.8 & 0.4 & 0.3 & 0.6 & 0.9 & 0.3 \\
\hline \multirow[t]{2}{*}{ LVB (cm) } & $\mathbf{M}$ & 5.1 & 5.8 & 4.7 & 3.7 & 5.0 & 4.3 & 4.0 & 3.9 & 3.7 & 3.7 \\
\hline & S.E. & 0.9 & 1.4 & 0.7 & 1.2 & 0.1 & 0.7 & 0.6 & 0.6 & 1.3 & 6.6 \\
\hline
\end{tabular}


of the experiment. An hour after the ligation of the coronary artery $\Sigma \mathrm{ST}$ and $\mathrm{nST}$ increased to $5.0 \pm 0.1 \mathrm{~cm}$ and $8.2 \pm 1.4$ respectively. The number of points with a considerable displacement of segment ST during AC decreased from $7.0 \pm 1.6$ at the beginning of the experiment to $6.2 \pm 0.6$ at the end. The change was not significant

The data obtained by macroscopic identification of necrotic changes in the whole ventricular wall had some interesting features (Table III). In the control group, the mass of the infarction was $14.34 \pm 1.98 \mathrm{Gm}$ per $100 \mathrm{Gm}$ of left ventricular myocardium, and the infarction mass volume was $16.60 \pm 2.02$ $\mathrm{cm}^{3}$ per $100 \mathrm{~cm}^{3}$ of left ventricular volume. The projection of the necrotic zone onto the frontal surface of the left ventricle had an area of $14.4 \pm 2.9$ $\mathrm{cm}^{2}$. The following data demonstrated the beneficial effects of intraaortic balloon pumping on myocardial necrosis: the infarction mass was $10.70 \pm$ $1.49 \mathrm{Gm}$ per $100 \mathrm{Gm}$ left ventricular myocardium and the infarction mass volume was $9.32 \pm 1.33 \mathrm{~cm}^{3}$ per $100 \mathrm{~cm}^{3}$ of left ventricular volume. The area

Table II. Changes of nST in the Control and Assisted Circulation Groups in Dogs

\begin{tabular}{|c|c|c|c|c|c|c|c|c|c|c|c|}
\hline $\begin{array}{l}\text { Time } \\
\text { nST }\end{array}$ & & $\begin{array}{l}\text { Ligation } \\
\text { of } \\
\text { coronary } \\
\text { artery }\end{array}$ & $\begin{array}{r}15 \\
\min \end{array}$ & $\begin{array}{r}30 \\
\min \end{array}$ & $\begin{array}{r}45 \\
\min \end{array}$ & $\begin{array}{r}60 \\
\min \end{array}$ & $\begin{array}{r}1 \mathrm{~h} \\
15 \\
\mathrm{~min}\end{array}$ & $\begin{array}{r}1 \mathrm{~h} \\
30 \\
\mathrm{~min}\end{array}$ & $\begin{array}{r}1 \mathrm{~h} \\
45 \\
\min \end{array}$ & $2 \mathrm{~h}$ & $\begin{array}{r}2 \mathrm{~h} \\
15 \\
\mathrm{~min}\end{array}$ \\
\hline \multirow[t]{2}{*}{ Control $(\mathrm{cm})$} & $\mathbf{M}$ & 7.0 & 7.6 & 7.8 & 8.0 & 9.2 & 8.4 & 9.0 & 9.0 & 7.2 & 6.3 \\
\hline & S.E. & 1.4 & 0.5 & 1.3 & 1.5 & 0.8 & 1.5 & 0.5 & 0.5 & 1.1 & 0.6 \\
\hline \multirow[t]{2}{*}{ IABP $(\mathrm{cm})$} & $\mathbf{M}$ & 6.8 & 8.3 & 8.3 & 7.0 & 6.0 & 6.0 & 5.0 & 7.3 & 6.3 & 6.0 \\
\hline & S.E. & 0.5 & 0.9 & 0.5 & 0.7 & 0.7 & 0.7 & 0.6 & 0.4 & 0.9 & 0.8 \\
\hline \multirow[t]{2}{*}{ LVB (cm) } & $\mathbf{M}$ & 7.0 & 7.2 & 7.4 & 6.6 & 8.2 & 5.8 & 5.7 & 6.6 & 6.5 & 6.2 \\
\hline & S.E. & 1.6 & 1.0 & 1.1 & 1.5 & 1.4 & 1.1 & 0.9 & 0.7 & 0.7 & 0.6 \\
\hline
\end{tabular}

$\mathrm{IABP}=$ intraaortic baloon pumping; $\mathrm{LVB}=$ left ventricular bypass.

Table III. Influence of Assisted Circulation on the Intensity of Necrosis in the Ventricular Wall

\begin{tabular}{|c|c|c|c|c|c|c|}
\hline & Control & IABP & LVB & $P_{1}$ & $\mathrm{P}_{2}$ & $P_{3}$ \\
\hline $\begin{array}{l}\text { Infarction mass per } \\
100 \mathrm{Gm} \text { of } \mathrm{my}- \\
\text { ocardium (Gm) }\end{array}$ & $14.34 \pm 1.98$ & $10.70 \pm 1.49$ & $8.10 \pm 1.31$ & $>0.05$ & $<0.55$ & $>0.05$ \\
\hline $\begin{array}{l}\text { Infarction mass } \\
\text { volume per } 100 \mathrm{~cm}^{3} \\
\text { of myocardium }\left(\mathrm{cm}^{8}\right)\end{array}$ & $16.60 \pm 2.02$ & $9.32 \pm 1.33$ & $5.92 \pm 1.31$ & $<0.05$ & $<0.05$ & $<0.05$ \\
\hline $\begin{array}{l}\text { MI area on LV } \\
\text { surface }\left(\mathrm{cm}^{2}\right)\end{array}$ & $14.4 \pm 2.9$ & $9.9 \pm 2.8$ & $7.2 \pm 1.5$ & $>0.05$ & $<0.05$ & $>0.05$ \\
\hline \multicolumn{7}{|c|}{$\begin{array}{l}P_{1}=\text { significant difference between control and intraaortic baloon pumping values; } P_{2}= \\
\text { significant difference between control and left ventricular bypass values; } P_{3}=\text { significant } \\
\text { difference between IABP and } L V B \text { values. } M I=\text { myocardial infarction; } L V=\text { left ventricle; } \\
\text { IABP=intraaortic balloon pumping; } L V B=\text { left ventricular bypass. Mean } \pm S . E \text {. }\end{array}$} \\
\hline
\end{tabular}


of the necrotic lesion projected upon the frontal wall of the left ventricle was $9.9 \pm 2.8 \mathrm{~cm}^{2}$. In the group with transaortic shunting of the left ventricle, more convincing data on the reduction of the necrotic lesion zone were obtained. The infarction mass was minimal in that group of animals: $8.10 \pm$ $1.31 \mathrm{Gm}$ per $100 \mathrm{Gm}$ of left ventricular myocardium. The volume of infarction mass was also minimal $\left(5.92 \pm 1.31 \mathrm{~cm}^{3}\right.$ per $100 \mathrm{~cm}^{3}$ of left ventricular volume). The projection of the necrotic zone on the surface of the left ventricle was $7.2 \pm 1.5 \mathrm{~cm}^{2}$.

\section{Discussion}

Although intraaortic balloon pumping has been in use as a method of assisted circulation on a large scale in cardiosurgical practice, as well as in the treatment of acute myocardial infarction and unstable angina, ${ }^{11)-14}$ it has certain disadvantages. Intraaortic counterpulsation assumes a priori cardiac work (in heart massage using a aortic pressure monitor as a source of synchronized impulses). Therefore, the use of AC methods is promising in resuscitation, because it may fully or partly take over the pumping function of the heart. The methods should be simple in construction and quick in application. The drainage of the left ventricle initiated by Dennis et al ${ }^{4)}$ meets these needs to a certain degree. However the method of inserting a rigid cannula into the left atrium by perforating interatrial septum from the right atrium causes trauma and is rather dangerous. That is why the insertion of a cannula for collecting blood from the left ventricle through the arterial system seems to be more promising. There are reports by Zwart et al ${ }^{8)}$ on the use of this method with relatively positive results.

We have chosen two methods for comparing the effectiveness of the two procedures for AC: the degree of ischemia in the area of experimental myocardial infarction was estimated from recordings from epicardial leads and macroscopic determination of the size of myocardial necrosis. The method of recording displacements of segment ST is attractive because of its simplicity, safety, and speed in the interpretation of final results. Thus it is very convenient for a comparative estimation of therapeutic measures under investigation. ${ }^{15)-18)}$ However, some reports state that there is no close link between the displacement of segment ST and the intensity of biochemical shifts in the myocardial tissue. ${ }^{19)}$ Therefore, only a direct recording of the viability of cardiac cells can serve as an absolute index of destruction of the heart tissue. Recordings of dehydrogenase activity in functionally healthy tissue and its absence in the necrotic zone gives a possibility to delineate the damaged area in the ventricular wall. ${ }^{10), 20}$ ) 
Our data show that assisted circulation, both by intraaortic counterpulsation and by shunting the left ventricle, favourably affects the myocardium and lowers the displacement of segment ST in epicardial leads. An analysis of data obtained from recording epicardial leads does not reveal significant differences in groups with AG. However, the results of macroscopic investigations of necrosis in groups with $\mathrm{AC}$ show a considerable decrease both of the necrotic zone in the ventricular wall and of the zone of the necrosis projected on the surface of the left ventricle, especially when shunting the left ventricle.

Thus, our investigation has established that the left ventricular bypass compared to intraaortic balloon pumping has a marked effect on the intensity of experimental myocardial infarction. At the same time it has been established that the dynamic control of the displacement level of segment ST in the epicardial leads may serve as an indication of the intensity and direction of pathological processes in the myocardial wall. However, this method does not give a strict quantitative evaluation of the size of the necrotic zone. The latter can be more adequately obtained by histochemical methods.

\section{REFERENGES}

1. Lamberty II, Anagnostopoulos CE, Al-Sadir I, Das Gupta DS, Chung-Yuan Lin, Replogle RL, Resnekov L, Skinner DB: Mechanical circulatory assistance for the treatment of complications of coronary artery disease. Surg Clin North Am 56: 83, 1976

2. Sanders CA, Buckley MI, Leinbach RC, Mundth ED, Austen WG: Mechanical circulatory assistance. Current status and experience with combining circulatory assistance, emergency coronary angiography and acute myocardial revascularisation. Circulation 45: 1292, 1972

3. Shumakov VI, Tolpekin VE: Assisted circulation: achevements and problems. Cardiologia (USSR) 1: 10, 1976

4. Dennis C, Hall DP, Moreno JR, Senning A: Left atrial cannulation without thoracotomy for total left heart bypass. Acta Chir Scand 123: 267, 1962

5. Hatano T, Omoto R, Ueda K, Yokote $\mathrm{Y}$ : The comparison of hemodynamic effects of concomitant use of intra-aortic balloon pumping and veno-arterial bypass with atrio-arterial bypass. Jpn Heart J 21 : 273, 1980

6. De Laria GA, Johansen KH, Levine JD, Bernstein EF : Reduction in myocardial ischemia by left ventricular bypass after acute coronary artery occlusion. J Thoracic Cardiovasc Surg 67: 826, 1974

7. Miller DR, Ashcraft W: Prolonged total left ventricular bypass in dogs. Arch Surg 108: 195,1974

8. Zwart HHJ, Kralios A, Kwan-Gett CS, Backman DK, Foote JL, Andrade JD, Calton FM, Schoonmaker F, Kolff W: First clinical application of transarterial closed-chest left ventricular (TaCLV) bypass. Trans Am Soc Artif Int Org 15: 386, 1970

9. Maroko PR, Kjekshus JK, Sobel BE, Braunwald E: Factors influencing infarct size following experimental coronary artery occlusion. Girculation 43: 67, 1971

10. Nachlas MM, Shnitka TK: Macroscopic identification of early myocardial infarcts by alterations in dehydrogenase activity. Am J Pathol 42: 379, 1963

11. Bardet J, Rigaud M, Kahn JC, Huret J, Gangjbakhch J, Bourdarias JP: Treatment of post-myocardial infarction angina by intra-aortic balloon pumping and emergency revas- 
cularization. J Thorac Cardiovasc Surg 74: 299, 1977

12. Bregman D: Success of clinical application of intraaortic balloon pumping. Cardiologia (USSR) $11: 92,1976$

13. Langou RA, Geha AS, Hammon GL, Cohen LS: Surgical approach for patients with unstable angina pectoris: role of the response to initial medical therapy and intraaortic balloon pumping in perioperative complications after aortocoronary bypass grafting. Am J Cardiol 42: 629,1978

14. Philips PA, Bregman D: Intraoperative application of intraaortic balloon counterpulsation determined by clinical monitoring of the endocardial viability ratio. Ann Thoracic Surg 23: 45,1977

15. Ashkenazi J, Maroko PR, Leisch M, Braunwald E: Usefulness of ST segment elevation as predictors of electrocardiographic signs of necrosis in patients with acute myocardial infarction. Brit Heart J 39: 764, 1977

16. Madias JE: Use of precordial ST-segment mapping. Am Heart J 95: 96, 1978

17. Selwyn AP, Ogunro EA, Shillingford JP: Natural history and evaluation of ST segment changes and $\mathrm{MB}$ CK release in acute myocardial infarction. Brit Heart J 39: 988, 1977

18. Vincent GM, Abildskov JA, Burgess MJ : Mechanisms of ischemic ST-segment displacement. Circulation 56: 559, 1977

19. Vial C, Font B, Goldschmidt D, Delaye J: Regional myocardial energetics during brief periods of coronary occlusion and reperfusion: comparison with ST segment changes. Cardiovasc Res 12: 470, 1978

20. Nachlas MM, Friedman MM, Cohen SP: A method for the quantitation of myocardial infarcts and the relation of serum enzyme levels to infarct size. Surgery 55: 700, 1964 